\title{
The Impact of Competitive Advantage on Purchasing Behaviour: Case of the Algerian User of a Mobile Network
}

\author{
Ahmed Medjedel ${ }^{1}$ \\ ${ }^{1}$ Taibah University, Madinah, Saudi Arabia \\ Correspondence: Ahmed Medjedel, Department of Marketing, CBA, Taibah University, PO box 41196, Madinah \\ 41521, Saudi Arabia. E-mail: aamgdal@taibahu.edu.sa, amedjedel@gmail.com or medjedela@yahoo.com
}

Received: February 3, 2013

Accepted: November 1, 2013 Online Published: January 22, 2014

doi:10.5539/ijms.v6n1p186

URL: http://dx.doi.org/10.5539/ijms.v6n1p186

\begin{abstract}
The competitive advantage is not enough to be an important and distinctive product attribute, but must be experienced by the consumer when making a purchase decision. This study will investigate the competitive advantage of the telecommunication network "Wataniya Telecom Algeria" which carries the trade name "Nedjma" as the first operator in multimedia services and its possible impact on the purchasing behaviour of the Algerian user. First, it should be verified that the phenomenon under consideration (competitive advantage) does really exist. Then a quantitative research through the investigation of a sample of mobile phone users in the Wilaya (county) of Algiers is conducted. The ultimate aim of the latter, using some statistical tools, is to determine the impact of this feature on the purchasing behaviour.
\end{abstract}

Keywords: competitive advantage, mobile telephony, purchasing behaviour, Algerian user, marketing

\section{Introduction}

Given the rapid changes and the successive needs of consumers, it is necessary for institutions to gain a competitive advantage, especially for mobile phone operators in Algeria. The Algerian economy used to be centrally planned based on a Soviet-like heavy industrializing model where most of the productive machine was state- owned (Medjedel, 1987). It was only very recently (1980-1990s) that a wave of economic liberalism swept through bringing up competition to many sectors of the national economy. One of the first sectors to experience competition were the mobile telecommunication networks. New foreign joint-ventures operators (Djezzy \& Nedjma) came in and joined the state-owned Mobilis. Nedjma was the first operator to launch the Multimedia service to Algerian users.

It is therefore, very interesting to investigate how can this operator gain a competitive advantage over his main rivals through the purchasing behaviour of those users.

Based on the foregoing, the problem of this study centred on the following main question:

What is the impact of the competitive advantage of the mobile operator "Nedjma" (Wataniya Telecom Algeria), on the purchasing behaviour of Algerian mobile users?

And as part of this main problem several sub-questions can be asked, including:

1) What are the characteristics of the mobile phone service which can affect the user preferences for deciding to go for the mobile phone?

2) What is the position of users of the "Nedjma" network as far as with regards to multimedia services offered by the network?

3) What are the personal characteristics of the user that can affect the use of multimedia services?

To answer this sub-questions, the following possible answers can be put forward in the form of hypotheses:

Hypothesis 1: Users of "Nedjma" network are not satisfied with the multimedia services (Multimedia) offered by the network.

Hypothesis 2: There is a core and statistically significant relationship between benefit of multimedia services (Multimedia) and the preference for subscription in the network of the mobile phone. 
Hypothesis 3: There is a core and statistically significant relationship between the educational level of the user and taking advantage of multimedia services (Multimedia).

\subsection{Importance of the Study}

The importance of the study stems from the following:

- Novelty of the subject, thus no field study undertaken on the subject as yet in the Algerian context.

- Drawing the attention of firms' managers to the need of paying attention to the competitive advantage from the viewpoint of the consumer.

- Showing the importance for Algerian firms to in-depth study of consumer behaviour, as that would have a crucial role in the success of marketing decisions taken.

- Importance of the telecommunications sector in Algeria, and his clear contributions to national economy.

- Importance of the telecommunications sector as a sensitive and strategic sector which also touches an important aspect of national sovereignty.

\subsection{The Structure of the Study}

In order to fully grasp the foundations and requirements of the study, a two-fold plan is retained. The first part addresses various conceptual theories and terminology related to the subject. The second part deals with the empirical study which makes sure the existence of competitive advantage through a bibliographical study and then determine the impact of this feature on the purchasing behaviour of users (quantitative study).

\section{Methodology}

The relationship between the methodological approach and the subject makes them synchronous. It is the nature of the topic that defines the approach to be followed in order to investigate its most important aspects. Therefore, the study will adopt a case study approach in the first part whereas the quantitative method is applied in the second empirical section. First, a qualitative study will be undertaken in order to verify the existence of competitive advantage in our case. Then a quantitative study is performed by investigating a sample of users of mobile phones within Algiers county to determine the impact of this feature on the purchasing behaviour of users. To do so we need to rely on some statistical tools, such as percentages for the sake of description, and statistical tests in order to analyse the obtained results.

\section{The Terminology and Theoretical Concepts}

\subsection{The Theory of Consumer Behaviour}

The consumer can be considered as the activation key for the company, he is instrumental in moving the local economy and global, as the decisions of the consumer purchasing power are of interest for marketing. Since understanding the stages and mechanism aspects affecting these decisions contributes much in the preparation of an effective marketing strategy. Given the importance of these stages, specialists in this area have developed several models which are in fact dependent on each other. An example of the proposed models is illustrated by the following theoretical model:

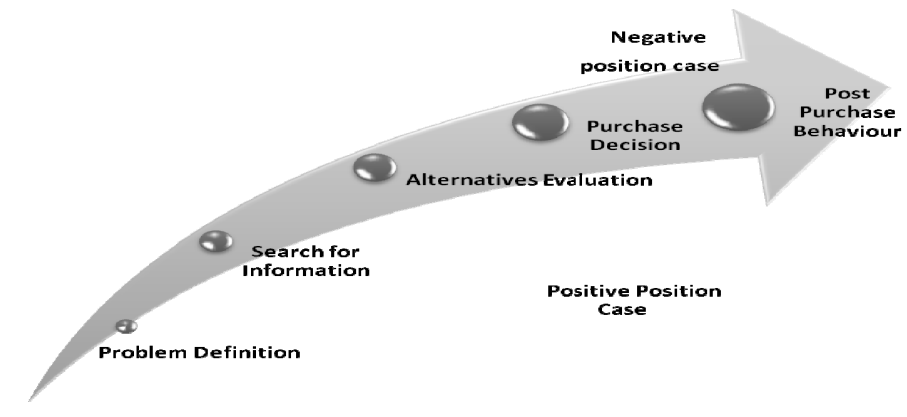

Figure 1. The purchasing decision-making stages

Source: Prepared by the researcher based on the works of Helfer \& Orsoni (2000), Kotler et al. (2006). 
The figure shows that the decision to purchase consists of five stages which are as follows:

\subsubsection{Identifying the Problem}

The process of purchasing decision- making begins when the consumer feels that he has a non-saturated need, in the form of a problem which consists of the difference between the current situation and the desired situation desired. The greater the severity of the need and the longer time it lasts the consumer becomes more determined to satisfy his need (Annabi, 2003)

\subsubsection{Look for Information}

After the first phase, begins the process of gathering information about the product from different locations by the consumer. This quest for information is first sparked by a cognitive internal process which examines the mental information stored which helps to make decisions. Then comes the process of the external research from a variety of sources as spelled out in the following (Al Menawi, 1998)

\subsubsection{Personal Sources}

This includes information collected from family, friends, neighbours and relatives, which can be considered as important sources because the consumer heavily trust them.

\subsubsection{Commercial Sources}

This includes information that has been collected from advertising, salesmen, presentation and packaging. These sources are available without any or little effort from the consumer.

\subsubsection{Public Sources}

This includes information collected from magazines, newspaper articles, radio, television and the Internet.

\subsubsection{Experimental Sources}

In this case, the consumer tests and uses items before the purchase decision-making by the consumer.

\subsubsection{The Stage of Evaluation of Alternatives}

The consumer at this stage assesses the solutions or alternatives that were collected during the previous phase. The evaluation should be in accordance with standards established by the consumer himself to help him find out a solution to his initial problem. Of course readably fixed standards as well as solutions proposed vary from consumer to another.

\subsubsection{The Stage of the Purchasing Decision}

There are several factors that may intervene before making the actual decision to buy, which may spoil the intention of purchasing.

\subsubsection{The Stage of Post-Purchase Behaviour}

The phase of post-purchase behaviour is meant to assess the suitability of the product to satisfy the buyer's needs and this would condition either negatively or positively future attitudes towards the same product/brand/producer.

Negative attitudes translate in a behaviour consisting of not acquiring these products again, and hence return to the stage of searching for information and to identify and evaluate alternatives.

On the other hand, positive attitude translates into re-buying this product again because the consumer feels satisfied with its use/consumption. This leads to achieve the required balance and to gain information and appropriate experience, and ultimately the brand loyalty of this product (Al Sumaidy, 1997)

\subsection{The Concepts of Competitive Advantage Theory}

According to Michael Porter (2000) the competitive advantage is not concerned with the state alone, but belong to the institution as well. The competitive advantage arises mainly from the value that an organization creates for its customers so that it can take the form of lower prices as compared to the prices of competitors with equal benefits or provide unique benefits in the product which make up consciously for the imposed price increase (Porter, 2000):

Also seen as a competitive advantage is, "the organization's ability to meet the needs of the consumer, or the value you wish to obtain out of the product, such as high-quality" (Khalil, 2008).

The process of gaining a competitive advantage is not an easy-going straightforward process. When the company provides a different product from the competition it does not necessarily mean that it has gained a competitive 
advantage. This so because gaining the competitive advantage over the competition is subject to several conditions that must be available and which could be mentioned in the following points, (Spitezki, 1995)

\subsubsection{Decisiveness}

The first condition of competitive advantage is to be decisive, and this means that this feature can be given precedence and superiority over competitors.

\subsubsection{The Possibility of Protection}

The second condition is to the possibility of defending the product as well the competitive advantage, especially from the imitation and forgery. The firm that cannot defend its gains, cannot say that it has a competitive advantage.

\subsubsection{Continuity}

The last condition is the continuity of competitive advantage, a condition of great importance. This feature if it does not last long cannot be considered as being a competitive advantage.

Through our review of these conditions, we can conclude that each condition is linked to one another, that is, they must be available all at the same time. Hence the lack of any condition means that the institution does not have a competitive advantage. However, it is difficult to maintain the provision of all these conditions at the same time for several reasons, among them:

- Requiring the "continuity of competitive advantage" is difficult to achieve, because of the current nature of business as well as the amazing amount of innovations related to changes in the product.

- Considering that efforts are being made by rival institutions to overcome the competitive advantage of the institution, especially by imitation.

- Changes in government restrictions, which include mainly the areas of product specifications.

Therefore, if the product offers a competitive advantage but it is not important for the consumer, it will not affect the purchase decision and subsequently, cannot be considered as a criterion for decision making. So it is not enough for the competitive advantage to be only different and important, but must be strongly felt by the consumer when making its decision of purchase.

\section{The Empirical Study on the Impact of Competitive Advantage on the Purchasing Behaviour}

This part of the study consists of an applied research by ensuring the existence of competitive advantage, first, based on the qualitative and desk study. Then by determining the impact of the feature under study on the consumer purchasing behaviour which would be based on the quantitative study through a survey.

\subsection{The Qualitative and Desk Study to Ensure the Existence of Competitive Advantage}

\subsubsection{The Desk Study}

Through desk study we have compiled some data which were available in the form of "user's guide" or in the form of "previous studies".

\subsubsection{Enterprise-Level (Manual Use)}

Shows us the evidence pertaining to the use of services provided by Watanya Telecom Algeria "Nedjma" that any user can take advantage of mobile multimedia services (Multimedia) including:

- $\quad$ Send and receive picture messages (MMS).

- Benefit from the services of the Internet and check e-mail (E-mail), from a mobile phone or from your computer by "Cable Data" for example.

- $\quad$ GPRS Services which are used to transfer data very quickly.

\subsubsection{Previous Studies}

There are few studies that addressed the theme of competitive advantage in the case of the Network Telecom "Nedjma" stating its position as a leading multimedia services (Multimedia), but it passed unnoticed mainly because it wasn't the core focus of these studies. These studies include (Djedid, 2008), (Amer, 2006), and (Benjeroua, 2007).

\subsubsection{Qualitative Studies}

This kind of studies are characterized by a low number of individuals who will be interviewed and are based on the principle that we do not know what is the actual reality. Said differently, "every person has different perception of 
what we know". This type of studies helps the researcher to know the variables to be measured, as well as assist him in the formulation of questions to be included in the questionnaire (quantitative study).

For our qualitative study, the method of direct personal interview has been used, where we have chosen a sample of 20 users of different telecommunications services providers (mobile phone networks) such as Nedjma, Mobilis, and Djezzy.

Several questions have been asked to make sure that the telecommunications network "Nedjma" do hold a competitive advantage. The result reached in all the interviews we held is that the competitive advantage do exist in this company and can be summarized in the following: "to be the first operator in multimedia services (Multimedia)".

Through the results of the desk and qualitative studies that we have made, it can be ascertained that the competitive advantage in that case really exist. That's what makes us continue our study to address the impact of this feature on the decision of purchasing through the quantitative study (survey).

\subsection{Determining the Impact of Competitive Advantage on the Consumer Purchasing Behaviour-Quantitative} Study

\subsubsection{Simple Scheduling}

Simple Scheduling contributes to make simple and clear overview of the results obtained in each variable separately, and to confirm the validity of the assumptions contained in the research based on only one variable.

\subsubsection{Having a Line of Mobile Phone}

Table 1. Having a line of mobile phone

\begin{tabular}{llll}
\hline & Has a line of mobile phone & Don't have a line of mobile phone & Total \\
\hline Occurrence & 369 & 0 & 369 \\
Percentage & $100 \%$ & $\% 0$ & $100 \%$ \\
\hline
\end{tabular}

Source: prepared by the researcher in the light of the results of the survey.

Through the table above, we can consider that all units of the chosen sample belongs to the research community studied.

\subsubsection{The Distribution of the Mobile Phone Subscription among Operators}

Table 2. The distribution of subscription by mobile phone operator

\begin{tabular}{lllll}
\hline & Djezzy & Mobilis & Nedjma & Total \\
\hline Occurrence & 111 & 73 & 185 & 369 \\
Percentage & $30.08 \%$ & $19.78 \%$ & $50.13 \%$ & $100 \%$ \\
\hline
\end{tabular}

Source: prepared by the researcher in the light of the results of the survey.

From the above table, the percentage of users in the network "Djezzy" was $30.08 \%$, while the proportion in the network "Mobilis" was estimated at $19.78 \%$, and finally the percentage in the network "Nedjma" made up the lion's share, that is $50.13 \%$.

4.2.1.3 Ensuring the Existence of a Competitive Advantage by the Network "Nedjma"

Table 3. To ensure that the competitive advantage of the network "Nedjma" did exist

\begin{tabular}{lllll}
\hline Points of excellence & Djezzy & Mobilis & Nedjma & Total \\
\hline Subscription rate is reasonable. & 61 & 205 & 103 & 369 \\
Attractive promotions (Promotion). & 104 & 140 & 125 & 369 \\
Pioneer in multimedia services (Multimedia). & 03 & 08 & 358 & 369 \\
Good coverage. & 125 & 100 & 144 & 369 \\
Good reputation. & 184 & 54 & 131 & 369 \\
The network share is with a national network. & 0 & 369 & 0 & 369 \\
\hline
\end{tabular}

Source: prepared by the researcher in the light of the results of the survey. 
Through the table above, it is demonstrated that the competitive advantage of the network "Nedjma" actually is a "pioneer in multimedia services (Multimedia)", and this is what we wanted to check.

Given the importance of the last point, we will clarify it through the following diagram:

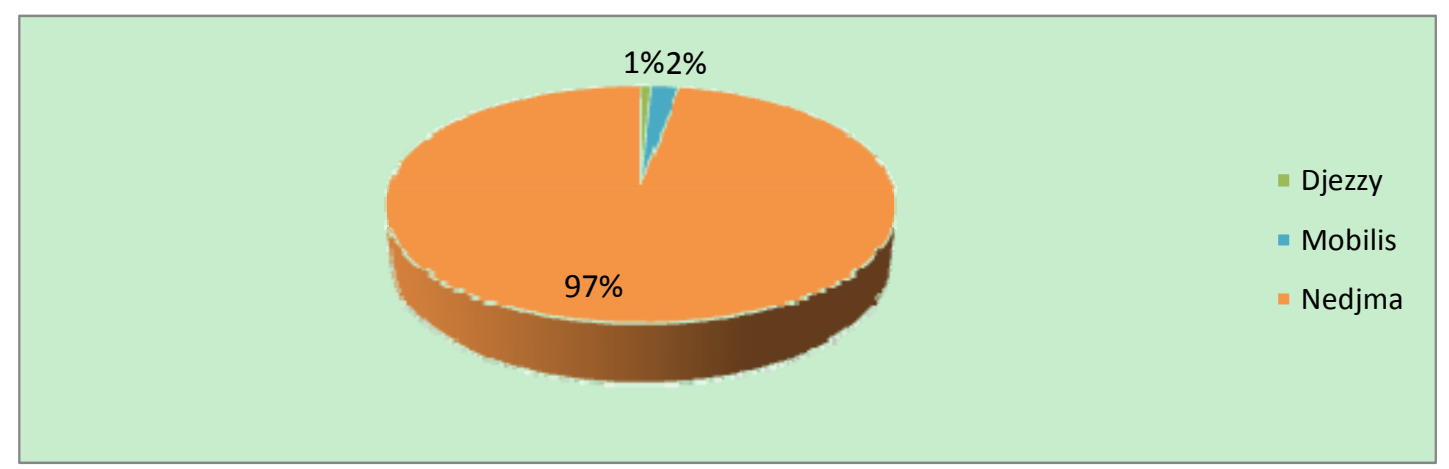

Figure 2. The availability of multimedia services (Multimedia)

Source: prepared by the researcher in the light of the results of Table 3.

Through the figure above, we see that multimedia services is the competitive advantage of network "Nedjma" where the usage percentage is $97 \%$ (almost 100\%) compared to tiny percentages of the remaining networks "Djezzy" and "Mobilis", which amounted to $1 \%, 2 \%$, respectively.

The existence of competitive advantage has ben confirmed through a qualitative study, but because this type of studies cannot lead to a universal generalization of its results. That is why a quantitative study becomes a must, where it can be easily checked again the existence of this feature (competitive advantage) which also indicates that the results could be generalized.

4.2.1.4 The Reasons for Selecting the Network

Table 4. Reasons for selecting the network

\begin{tabular}{|c|c|c|c|c|c|c|c|}
\hline Why & $\begin{array}{l}\text { Very } \\
\text { Insignificant }\end{array}$ & Insignificant & Unknown & Significant & $\begin{array}{l}\text { Very } \\
\text { Significant }\end{array}$ & Coefficient & Ranking \\
\hline Subscription rate is reasonable. & 84 & 77 & 51 & 66 & 91 & 3 & 6 \\
\hline Promotions (Promotion). & 25 & 36 & 44 & 114 & 150 & 328 & 2 \\
\hline Pioneer in multimedia services (Multimedia). & 35 & 35 & 54 & 138 & 107 & 247 & 3 \\
\hline Good coverage. & 62 & 53 & 50 & 115 & 89 & 116 & 4 \\
\hline Most friends are involved in the same network. & 18 & 22 & 31 & 99 & 199 & 439 & 1 \\
\hline The network share is with a national network. & 67 & 83 & 37 & 117 & 65 & 30 & 5 \\
\hline
\end{tabular}

Source: prepared by the researcher in the light of the results of the survey.

Through the table above, it is noted that subscribing in the multi-media services occupies the third rank, and this indicates the importance of these services for the users of mobile phone.

4.2.1.5 Sources of Information on Users of "Nedjma"

Table 5. Sources of information for users of the "Nedjma" network

\begin{tabular}{|c|c|c|c|c|c|c|c|}
\hline Source of information & $\begin{array}{l}\text { Very } \\
\text { Insignificant }\end{array}$ & Insignificant & Unknown & Significant & $\begin{array}{l}\text { Very } \\
\text { Significant }\end{array}$ & Coefficient & Ranking \\
\hline Friends & 5 & 8 & 7 & 40 & 125 & 272 & 1 \\
\hline Ads on television & 49 & 28 & 8 & 45 & 55 & 29 & 5 \\
\hline Daily newspapers & 7 & 9 & 39 & 29 & 101 & 208 & 2 \\
\hline
\end{tabular}




\begin{tabular}{llllllll}
\hline Advertising signs on the roads & 26 & 31 & 28 & 31 & 69 & 86 & 4 \\
Commercial agents & 11 & 13 & 44 & 40 & 77 & 159 \\
\hline
\end{tabular}

Source: prepared by the researcher in the light of the results of the survey.

Through the above table, the sources from which users of "Nedjma" acquired information on the services provided by the Network, are ranked by importance in as follows:

1 - Friends.

2 - Daily newspapers.

3 - Trading agents.

4 - Advertising panels in the streets.

5 - Ads on television.

And these results can assist the company in the selection of the appropriate media in order to promote its competitive advantage and setting the budget allocated to each media outlet.

4.2.1.6 Characteristics of the Published Information in Term of Sufficiency and Persuasion

Table 6. Characteristics of the published information in terms of sufficiency

\begin{tabular}{llllll}
\hline \multicolumn{5}{c}{ Is not quite enough Just enough No opinion Sufficient Quite enough Total } & Coefficient \\
\hline Occurrence 42 & 37 & 39 & 37 & 30 & 185 \\
Percentage $22.7 \%$ & $20 \%$ & $21.08 \%$ & $20 \%$ & $16.21 \%$ & $100 \%$ \\
\hline
\end{tabular}

Source: prepared by the researcher in the light of the results of the survey.

Through the table above, it is noted that the negative coefficient (-24), means that the published information remains insufficient, resulting in some questions or misunderstandings by the users who have some of points they would like to highlight but without finding the right answers.

4.2.1.7 Characteristics of the Information Published in Terms of the Degree of Convincing

Table 7. Characteristics of the information published in terms of the degree of convincing

\begin{tabular}{lllllll}
\hline \multicolumn{5}{c}{ Not very convincing Little convincing No opinion Convincing Quite convincing Total Coefficient } \\
\hline Occurrence 43 & 41 & 13 & 67 & 21 & 185 & 18 - \\
Percentage $23.24 \%$ & $22.16 \%$ & $7.02 \%$ & $36.21 \%$ & $11.35 \%$ & $100 \%$ \\
\hline
\end{tabular}

Source: prepared by the researcher in the light of the results of the survey.

Through the table above, it is also noted that the negative coefficient (-18) which indicates that the information published remains unconvincing, partly also because, as we have seen in table 6., of its insufficiency.

4.2.1.8 Reasons for Choosing to Subscribe in the Network "Nedjma"

Table 8. Reasons for preferring the network "Nedjma"

\begin{tabular}{|c|c|c|c|c|c|c|c|}
\hline Source of information & $\begin{array}{l}\text { Very } \\
\text { Insignificant }\end{array}$ & Insignificant & Unknown & Significant & $\begin{array}{l}\text { Very } \\
\text { Significant }\end{array}$ & Coefficient & Ranking \\
\hline Subscription rate. & 56 & 64 & 2 & 23 & 40 & $73-$ & 5 \\
\hline Dual service calls. & 63 & 51 & 22 & 19 & 30 & $98-$ & 6 \\
\hline Good coverage. & 49 & 0 & 57 & 48 & 31 & 12 & 4 \\
\hline Call Forwarding. & 63 & 59 & 33 & 1 & 29 & $126-$ & 7 \\
\hline Multimedia services & 21 & 56 & 20 & 25 & 63 & 53 & 2 \\
\hline Pricing of international calls. & 34 & 26 & 50 & 15 & 60 & 41 & 3 \\
\hline Pricing of local calls. & 29 & 31 & 31 & 20 & 74 & 79 & 1 \\
\hline
\end{tabular}

Source: prepared by the researcher in the light of the results of the survey. 
Through the table above, the reasons for choosing to subscribe in the network "Nedjma" according to various reason (criteria) and based on the inherent coefficient can be spelt as follows:

1) Pricing of local calls.

2) Multimedia services (Multimedia).

3) Pricing of international calls.

4) Good coverage.

5) Subscription rate.

6) Dual service calls.

7) Call Forwarding.

The importance of multimedia services as a good reason to subscribe in the network "Nedjma" can be clearly seen, by occupying the second place after the "pricing of local calls."

\subsubsection{Individuals Affecting the Decision to Subscribe}

Table 9. Individuals affecting the decision to subscribe

\begin{tabular}{|c|c|c|c|c|c|c|c|}
\hline Individuals & $\begin{array}{l}\text { Very } \\
\text { Insignificant }\end{array}$ & Insignificant & Unknown & Significant & $\begin{array}{l}\text { Very } \\
\text { Significant }\end{array}$ & Coefficient & Ranking \\
\hline Friends. & 23 & 50 & 0 & 44 & 68 & 84 & 1 \\
\hline The family. & 0 & 69 & 22 & 49 & 45 & 70 & 2 \\
\hline $\begin{array}{l}\text { Prominent figures appearing in ads (e.g. } \\
\text { Zidane). }\end{array}$ & 49 & 61 & 18 & 23 & 34 & $68-$ & 3 \\
\hline Friends. & 23 & 50 & 0 & 44 & 68 & 84 & 1 \\
\hline The family. & 0 & 69 & 22 & 49 & 45 & 70 & 2 \\
\hline $\begin{array}{l}\text { Prominent figures appearing in ads (e.g. } \\
\text { Zidane). }\end{array}$ & 49 & 61 & 18 & 23 & 34 & $68-$ & 3 \\
\hline Friends. & 23 & 50 & 0 & 44 & 68 & 84 & 1 \\
\hline
\end{tabular}

Source: prepared by the researcher in the light of the results of the survey.

Through the table above, individuals are arranged in terms of the degree of influence on the decision to subscribe as follows:

1 - friends.

2 - the family.

3 - prominent figures appearing in the ads (Zidane).

The eminent persons that appear in the advertisements (e.g. Zidane) did not affect the decision to participate which is a logical consequence because the ads on television was ranked last as a source of information collected from users in order to subscribe in the network "Nedjma".

\subsubsection{Expression of the Degree of Satisfaction}

Table 10. The expression of the degree of satisfaction

\begin{tabular}{|c|c|c|c|c|c|c|c|}
\hline Individuals & $\begin{array}{l}\text { Very } \\
\text { Insignificant }\end{array}$ & Insignificant & Unknown & Significant & $\begin{array}{l}\text { Very } \\
\text { Significant }\end{array}$ & Coefficient & Ranking \\
\hline Services provided by the "customer services". & 81 & 62 & 3 & 39 & 0 & $185-$ & 7 \\
\hline Dual service calls. & 0 & 53 & 81 & 51 & 0 & $2-$ & 5 \\
\hline Good coverage. & 18 & 43 & 0 & 84 & 40 & 85 & 3 \\
\hline Call Forwarding. & 0 & 57 & 94 & 56 & 0 & $1-$ & 4 \\
\hline Multimedia services (Multimedia). & 32 & 69 & 23 & 61 & 0 & $72-$ & 6 \\
\hline Pricing of international calls. & 0 & 18 & 51 & 52 & 64 & 162 & 1 \\
\hline Pricing of local calls. & 0 & 30 & 35 & 61 & 59 & 149 & 2 \\
\hline
\end{tabular}

Source: prepared by the researcher in the light of the results of the survey. 
Through the table above, the services provided by the "Nedjma" have been arranged according to the degree of satisfaction as follows:

1) Pricing of international calls.

2) Pricing of local calls.

3) Good coverage.

4) Call Forwarding.

5) Dual service calls.

6) Multimedia services (Multimedia).

7) Services provided by the "customer services".

Note: This arrangement allows us to check the validity of the hypothesis that "Nedjma" subscribers are not satisfied with the multimedia services offered by this network, as well as the negative coefficient of these services $(-72)$.

\subsubsection{Expression of the Degree of Dissatisfaction}

Table 11. The expression of the degree of dissatisfaction

\begin{tabular}{llllll}
\hline Possible Actions & $\begin{array}{l}\text { Notify the people close to } \\
\text { you about your complaints }\end{array}$ & $\begin{array}{l}\text { Give up your subscription } \\
\text { in the network "Nedjma" }\end{array}$ & $\begin{array}{l}\text { Contact the } \\
\text { "customer } \\
\text { services". }\end{array}$ & Do nothing Total \\
\hline Occurrence & 79 & 23 & 102 & 15 & 219 \\
Percentage & $36.07 \%$ & $10.5 \%$ & $46.57 \%$ & $6.85 \%$ & $100 \%$ \\
\hline
\end{tabular}

Source: prepared by the researcher in the light of the results of the survey.

Through the above table, the total number of users who are not pleased with their subscription in the network "Nedjma" is 81 individuals, but the total responses are greater $(219>81)$, because those surveyed sometimes choose two answers or more, as illustrated through the example below:

\section{Example:}

People surveyed may express dissatisfaction through informing the people close to them as well as complaining directly by contacting the "customer services", in this case they select two answers.

It is also noted that the expression of the degree of dissatisfaction with the large rate of $46.57 \%$ through contacting "customer services", followed by the informing the persons close to complainants by $36.07 \%$, and after that comes the possibility of abandoning Subscription by $10.5 \%$, while the remaining $6.85 \%$ is the percentage of users who did not express dissatisfaction.

\subsubsection{Gender}

Table 12. Gender

\begin{tabular}{llll}
\hline & Male & Female & Total \\
\hline Occurrence & 153 & 32 & 185 \\
Percentage & $82.7 \%$ & $17.3 \%$ & $100 \%$ \\
\hline
\end{tabular}

Source: prepared by the researcher in the light of the results of the survey.

Through the above table, the percentage of surveyed male is $82.7 \%$, while the percentage of females is $17.3 \%$. 


\subsubsection{Age}

Table 13. Age

\begin{tabular}{llllll}
\hline & $\begin{array}{l}\text { Less than } \\
18 \text { years old }\end{array}$ & $18-29$ years & $30-49$ years & $\begin{array}{l}\text { More than } \\
50 \text { years }\end{array}$ & Total \\
\hline Occurrence & 0 & 106 & 62 & 17 & 185 \\
Percentage & $0 \%$ & $57.3 \%$ & $33.15 \%$ & $9.19 \%$ & $100 \%$ \\
\hline
\end{tabular}

Source: prepared by the researcher in the light of the results of the survey.

Through the above table, it can be seen that the percentage of people aged between 18 to 29 years is $57.3 \%$, followed by the proportion of people aged between 30 to 49 years with $33.15 \%$, while the proportion of individuals over the age of 50 years is $9.19 \%$. Finally, it can be said that the sample that was selected did not contain individuals under 18 years old.

\subsubsection{Monthly Income}

Table 14. Monthly income in Algerian Dinars (A.D.)

\begin{tabular}{llllll}
\hline & Less than 12,000 & $12.000-19.000$ & $20.000-29.000$ & More than & Total \\
& A.D. & A.D. & A.D. & 30,000 A.D. & \\
\hline Occurrence & 0 & 64 & 111 & 10 & 185 \\
Percentage & $0 \%$ & $34.6 \%$ & $60 \%$ & $5.4 \%$ & $100 \%$ \\
\hline
\end{tabular}

Source: prepared by the researcher in the light of the results of the survey.

Through the above table, it can be seen that the percentage of those who earn a monthly income ranging from 20.000 to 29.000 A.D. represent $60 \%$, followed by the percentage of those who earn a monthly income ranging from 12,000 to 19.000 A.D. at $34.6 \%$, then the proportion of people whose income exceeds 30.000 A.D. at $5.4 \%$, while the sample contains no one earning less than 12,000 Dinars.

\subsubsection{Education Level}

Table 15. Level of education

\begin{tabular}{llllll}
\hline & Primary & Mid-school & Secondary & University & Total \\
\hline Occurrence & 2 & 38 & 64 & 81 & 185 \\
Percentage & $1.08 \%$ & $20.54 \%$ & $34.59 \%$ & $43.78 \%$ & $100 \%$ \\
\hline
\end{tabular}

Source: prepared by the researcher in the light of the results of the survey.

Through the above table, it is shown that the percentage of undergraduates took the lion's share, reaching $43.78 \%$, followed by percentage of those who have a secondary level, which reached $34.59 \%$, and for those with medium level they accounted for $20.54 \%$, but the low proportion recorded was $1.08 \%$, which is especially for people who have the Primary level.

\subsubsection{Professional and Social Situation}

Table 16. Professional and social status

\begin{tabular}{lllllll}
\hline & Student & Managers & $\begin{array}{l}\text { Liberal } \\
\text { profession }\end{array}$ & $\begin{array}{l}\text { Civil } \\
\text { Servant }\end{array}$ & Retired & Total \\
\hline Occurrence & 0 & 36 & 63 & 71 & 15 & 185 \\
Percentage & $0 \%$ & $19.46 \%$ & $34.05 \%$ & $38.38 \%$ & $8.01 \%$ & $100 \%$ \\
\hline
\end{tabular}

Source: prepared by the researcher in the light of the results of the survey. 
Through the table above, it is noted that the largest percentage recorded is the ratio of civil servant amounting to $38.38 \%$, followed by the proportion of self-employed liberals at $34.05 \%$, then the proportion of managers that are estimated at $19.46 \%$, then the proportion of retired at $8.01 \%$. It should also be noted that the sample selected did not contain any students.

\subsubsection{Overlap Scheduling}

The main objective of this kind of scheduling is to determine the relationship between two variables, it can be also used as a reliable basis for several statistical tests such as $\chi^{2}$ tests.

\subsubsection{Verify Hypothesis 1}

There is a substantial statistically significant relationship between benefiting from multimedia services (Multimedia) and the preference for subscription in the mobile phone network.

Take advantage of multimedia services: $\mathbf{X}$

Preference to subscribe to a mobile phone network: $\mathbf{Y}$

$\mathbf{H}_{0:} \chi_{s}^{2}<\chi_{t}^{2}$ (there is no relationship between the two variables $\mathrm{X}$ and $\mathrm{Y}$ )

$\mathbf{H}_{1:} \chi_{s}^{2}>\chi_{t}^{2}$ (there is a relationship between the two variables $\mathrm{X}$ and $\mathrm{Y}$ )

Table 17. Taking advantage of multimedia services and its relationship to subscription preferences

\begin{tabular}{lllllll}
\hline & $\begin{array}{l}\text { Very } \\
\text { Insignificant }\end{array}$ & Insignificant & Unknown & Significant & $\begin{array}{l}\text { Very } \\
\text { Significant }\end{array}$ & Total \\
\hline Nedjma & 18 & 15 & 29 & 50 & 73 & 185 \\
Djezzy & 12 & 11 & 38 & 24 & 26 & 111 \\
Mobilis & 6 & 8 & 11 & 26 & 22 & 73 \\
Total & 35 & 35 & 54 & 138 & 107 & 369 \\
\hline
\end{tabular}

Source: prepared by the researcher in the light of the results of the survey.

We have: $\left(\chi_{s}^{2}=2.30\right)$, While $\left(\chi_{t}^{2}=15.51\right)$ And this is so when the degree of freedom is (8) And the level of risk is (0.05); That is: $\chi_{s}^{2}<\chi_{t}^{2}$

Accordingly, hypothesis $\mathrm{H}_{0}$ is accepted and thus the alternative hypothesis $\mathrm{H}_{1}$, is rejected which confirms the invalidity of the hypothesis saying: "that there is a substantial statistical significance between the demand for subscription and taking advantage of the multimedia services.

\subsubsection{Verify Hypothesis 2}

There is a substantial statistical significance between the educational level of the user and taking advantage of multimedia services (Multimedia).

Educational level of the user: $\mathrm{X}$

Taking advantage of the multimedia services: $\mathrm{Y}$

$\mathbf{H}_{\mathbf{0}}:\left(\chi_{s}^{2}<\chi_{t}^{2}\right)$ (there is no relationship between the two variables $\mathrm{X}$ and $\mathrm{Y}$ )

$\mathbf{H}_{1:}\left(\chi_{s}^{2}>\chi_{t}^{2}\right)$ (there is a relationship between the two variables $\mathrm{X}$ and $\mathrm{Y}$ )

Because of the conditions of application of $\chi^{2}$ test which states that the value should not be less than 5 iterations for each sample, a sample of primary level has been added to the sample of mid-school level and put them in one cell.

Table 18. Make use of multimedia services and its relationship to educational level

\begin{tabular}{lllllll}
\hline & $\begin{array}{l}\text { Very } \\
\text { Insignificant }\end{array}$ & Insignificant & Unknown & Significant & $\begin{array}{l}\text { Very } \\
\text { Significant }\end{array}$ & Total \\
\hline Primary-Mid & 8 & 11 & 7 & 6 & 8 & 40 \\
Secondary & 7 & 26 & 6 & 8 & 17 & 64 \\
University & 6 & 19 & 7 & 11 & 38 & 81 \\
Total & 21 & 56 & 20 & 25 & 63 & 185 \\
\hline
\end{tabular}

Source: prepared by the researcher in the light of the results of the survey. 
We have: $\left(\chi_{s}^{2}=16.91\right)$, While $\left(\chi_{t}^{2}=15.51\right)$ And this is so when the degree of freedom is (8) And the level of risk is (0.05); That is: $\chi_{s}^{2}>\chi_{t}^{2}$.

Accordingly, hypothesis $\mathrm{H}_{0}$, has been rejected and thus the alternative hypothesis $\mathrm{H}_{1}$, retained and this confirms Hypothesis 2, which says: that "there is a substantial statistical significance between the educational level of the user and taking advantage of the multimedia services".

\section{Conclusion}

The telecommunication sector in general, and communication via mobile phones in particular, witnesses a rapid development in Algeria, since the entry of foreign operators in accordance with the implementation of the Act 03-2000, dated on 05 August 2000 pertaining to reforming this sector.

Under this Law the foreign operator "Orascom Telecom Algeria", which carries the trade name "Djezzy" first entered the market, after it was the national operator "Algeria Mobile Telecom" which carries the trade name "Mobilis" the only player in the market. Then follows the foreign operator "Watanyia Telecom Algeria", which carries the trade name "Nedjma" to be the third mobile network in Algeria. The latter, in order to enhance its position in the market and win a bigger market share, has offered a competitive advantage embodied in "the first multimedia services (Multimedia)" in Algeria with the intention of influencing the purchasing behaviour of the Algerian user.

Accordingly, our approach in order to tackle the above problem can be succinctly summarized as follows: What is the impact of competitive advantage for the firm "Wataniya telecom Algeria" (Nedjma) on the purchasing behaviour?

\subsection{The Results of the Study}

The main findings of this field study, are:

- It has been confirmed that the competitive advantage of the firm "Wataniya Telecom Algeria" is really to be "the first operator in multimedia services (Multimedia)".

- The first hypothesis, which maintains that users of the mobile network "Nedjma" are not satisfied with the multimedia services (Multimedia), has been validated.

- While the second hypothesis, which suggests that there is a substantial statistically significant relationship between the benefit of multimedia services (Multimedia), and preference for subscription in the network of the mobile phone, was rejected.

- The third hypothesis, which maintains that there is a substantial statistical significance between the educational level of the user, and taking advantage of multimedia services (Multimedia) was verified.

\subsection{Suggestions and Recommendations}

Based on previous results, it can be concluded what follows:

- In light of changing tastes of users, the firm must undertake from time to time, qualitative and quantitative studies in order to keep pace with these changes.

- $\quad$ The firm should launch some promotional offers, all aimed at informing and convincing users about services that are available.

- $\quad$ The firm ought to give up its competitive advantage consisting of being "the first operator in multimedia services", and build is another advantage which stems from the needs and desires of users.

- $\quad$ The firm should improve its customer services, in order to provide a goodwill image.

\subsection{Limitations of the Study}

- $\quad$ The scope of this study pertains to the telecommunications market for mobile phone, highlighting Algiers marketplace from which we have derived a representative sample.

- Competitive advantage in the study is the first operator in multimedia services (Multimedia).

- We care in this study solely about the end-user excluding any reference to business users (institutions).

- We care during this study about corporate competitive advantage excluding any reference to nations competitive advantages. 


\section{References}

Al Menawi, A. (1998). Consumer Bahaviour, Concepts \& Strategies (2nd ed., pp. 31-32). Cairo: Ain Shams Library, Egypt (Arabic).

Al Sumaidy, M., \& Osman, Y. (1997). Consumer Behaviour, a Quantitative \& Analytical approach (pp. 113-114). Amman: Dar Al Manaheej for publishing \& distribution, Jordan (Arabic).

Amer, L. (2006). The impact of price on the purchasing decision-making : the case of servieces provided by the sector of mobile phone. Unpublished Dissertation (Arabic) The University of Algiers, Faculty of Economics and Management, Algeria.

Annabi, B. (2003). Consumer Bahaviour, the impact of Environmental factors (pp. 56-57). Tome 2, Algiers: University Publishing Office (OPU), Algeria (Arabic).

Benjaroua, H. (2007). The role of Marketing strategies in improving the services of telecommunication companies-The case of mobile telephony in Algeria. Unpublished Dissertation (Arabic), The University Saad Dahleb Blida, Faculty of Economics and Management, Algeria.

Djedid, A. (2008). Les Associations a l'image de marque dans les services. Cas de trois marque de la Téléphonie mobile en Algerie: Mobilis, Djezzy, Nedjma. Unpublished Master Thesis, University of Algiers, Ecole Supérieure de Commerce, (French), Algeria.

Helfer, J. P., \& Orsoni, J. (2002). Marketing (6th ed.). Paris: Vuibert France.

Khalil, N. (1998). The competitive Advantage in the field of Business. Alexandria : The Alexandria Book Centre, Egypt (Arabic).

Kotler, P., Dubois, B., Keller, K., \& Manceau, D. (2006). Marketing Management (12th ed.). Paris: Pearson Education, France

Medjedel, A. (1987). Science, technology \& development in Less-Developed Countries: The Algerian case 1962-1986. An unpublished Mphil thesis, Leeds University, UK.

Porter, M. (2000). L' Avantage Concurrentiel. Paris: Dunod, France.

Spitezki, H. (1995). La Stratégie d'Entreprise, compétitivité et mobilité. Paris: Edition Economica, France.

\section{Copyrights}

Copyright for this article is retained by the author(s), with first publication rights granted to the journal.

This is an open-access article distributed under the terms and conditions of the Creative Commons Attribution license (http://creativecommons.org/licenses/by/3.0/). 